\title{
ARTICLE
}

\section{The Impact of Brexit on the Environment: Exploring the Dynamics of a Complex Relationship}

\author{
Chris Hilson*
}

First published online 20 November 2017

\begin{abstract}
The departure of the United Kingdom (UK) from the European Union (EU) (often referred to as 'Brexit') is likely to have a significant impact on the environment. In this article I argue against seeing the traffic as all one way. While there was a temptation for the advocates of staying in the $\mathrm{EU}$, in the context of referendum campaigning, to portray the UK as a laggard pressured into positive environmental performance by the $\mathrm{EU}$ as leader, the reality is that the UK has also strengthened the EU's environmental policy in some areas and seen its own weakened in others. Influence in both directions has also varied over time. The article goes on to consider core 'Leave' arguments around sovereignty and 'taking back control', exploring the implications of these in the specific context of environmental governance. In discussing subsidiarity, it concludes that leaving the EU will not remove the need for pooling some sovereignty over environmental matters at the international level and, in the context of devolution, at the UK level.
\end{abstract}

Keywords: Brexit, Environment, Sovereignty, Control, Subsidiarity, Governance

\section{INTRODUCTION}

There have been a number of excellent, comprehensive studies on the environmental implications of the United Kingdom (UK) leaving the European Union (EU), often referred to as 'Brexit'. ' Detailed as these existing studies are, they do not always

* University of Reading (United Kingdom (UK)).

Email: c.j.hilson@reading.ac.uk.

Earlier versions of this article were presented at the workshop 'Re-Imagining Environmental Law in an Age of Sovereignty and Control', University of Edinburgh (UK), 23 Nov. 2016; at the workshop 'The Future of European Policy in the European Union', University of Gothenburg (Sweden), 19-20 Jan. 2017; and at the British Academy, 'Brexit and the Environment: A Roundtable', 30 Jan. 2017. I am grateful for comments from those present and the journal's referees.

1 Environmental Audit Committee (EAC), Third Report of Session 2015-16, 'EU and UK Environmental Policy', HC 537, 19 Apr. 2016, available at: https://publications.parliament.uk/pa/cm201516/cmselect/ cmenvaud/537/537.pdf; Institute for European Environmental Policy (IEEP), 'Brexit: The Implications for UK Environmental Policy and Regulation', Mar. 2016, available at: https://ieep.eu/uploads/articles/ attachments/27e7d452-5435-46a5-9589-f6941e3febbc/IEEP_2016_Brexit_-_Implications_for_UK_ 
systematically set out the dynamic interaction between the UK and the EU, with influence - both positive and negative - travelling in both directions over time and across different policy areas in the field of environmental policy. Nor do they necessarily unpick the various factors which have a bearing on any assessment of whether leaving the EU is likely to be environmentally deleterious. In this article I aim to do both of these.

The article consists of two parts. In the first part, I consider the potential impact of Brexit on environmental policy and hence environmental quality. While this part considers the potential practical consequences, the second then considers the normative consequences of Brexit for issues of sovereignty and control - issues which featured strongly in the referendum debates. I argue that subsidiarity is central to the discussion and that repatriating environmental competence will typically fail to produce the desired level of effective control over environmental problems. I also highlight, as others have, that environmental sovereignty, once returned from Brussels, gives rise to questions about environmental federalism within the UK and the appetite of devolved administrations for a degree of Brussels-replacing central control. Both parts of the article therefore concern the title's 'impact of Brexit on the environment': the first part covers environmental policy and quality; the second part relates to environmental governance.

In deciding whether Brexit is likely to be good or bad for the environment in policy terms, it is important to note that any such assessment is inevitably value-laden. Although Table 1 below presents a form of ledger of positive and negative aspects of Brexit, the discussion that follows illustrates that there may be room for reasonable disagreement on where a policy is placed. Different sides may be equally committed to environmental protection, but have competing visions of the best policy means for achieving this. ${ }^{2}$ The EU Emissions Trading System (ETS) is a good example. To what extent one regards the ETS as a force for good is likely to depend in part on one's faith in market-based instruments. Moreover, while this article focuses mostly on the potentially environmentally deleterious impact of Brexit on the specific policy areas that constitute the EU's environmental acquis, it is also worth observing that some believe the very nature of the EU as a growth-based trading block as a whole is environmentally harmful and that the UK would therefore be better off out. ${ }^{3}$

Environmental_Policy_and_Regulations.pdf?v=63664509944; C. Burns et al., 'The EU Referendum and the UK Environment: An Expert Review' (2016), available at: http://ukandeu.ac.uk/wp-content/ uploads/2016/04/Expert-Review_EU-referendum-UK-environment.pdf; C. Burns, A. Jordan \& V. Gravey, 'The EU Referendum and the UK Environment: The Future under a "Hard" and a "Soft" Brexit' (2016), available at: http://ukandeu.ac.uk/wp-content/uploads/2016/08/The-Environment-underSoft-or-Hard-Brexit.pdf; HM Government, 'Review of the Balance of Competences between the United Kingdom and the European Union: Environment and Climate Change' (2014), Ch. 2; V. Heyvaert \& A. Cavoški, 'UK Environmental Law Post-Brexit', in M. Dougan (ed.), The UK After Brexit (Intersentia, 2017), pp. 115-33.

2 E.g., the UK Environment Secretary, Michael Gove, has stated: 'While the EU has often been a force for good in raising environmental standards, some of the means haven't necessarily been the most effective regulatory tools - so getting those right will be critical to Brexit success' (R. Harrabin, 'Brexit "Will Enhance” UK Wildlife Laws - Gove', BBC News, 19 June 2017, available at: http://www.bbc.co.uk/ news/science-environment-40331919).

3 E.g., J. Jones, 'The EU is an Outsized Behemoth Beyond Reform: The Green Case for Brexit', The Guardian, 8 June 2016, available at: https://www.theguardian.com/commentisfree/2016/jun/08/ 
Table 1 The Impact on Environmental Policy of UK Membership of the EU

\begin{tabular}{l|ll}
\hline \multirow{2}{*}{$\begin{array}{l}\text { Polity } \\
\text { Impacted }\end{array}$} & \multicolumn{2}{|c}{ Policy Outcome } \\
\cline { 2 - 3 } & Negative & Positive \\
\hline \multirow{2}{*}{ EU } & EU policy diluted by UK membership & EU policy strengthened by UK membership \\
& Air quality & Climate change (targets, recent EU ETS, and external \\
& Fracking & policy, but not renewables or energy efficiency) \\
& Energy efficiency & Common Agricultural Policy (CAP) \\
& Soils & Common Fisheries Policy (CFP) \\
& EU Emissions Trading System (ETS) & Integrated Pollution Prevention and Control (IPPC)/ \\
& (early) & Industrial Emissions Directive (IED) \\
& & Habitats (early) \\
& UK diluted by EU & \\
& CAP & UK strengthened by EU \\
& CFP & Bathing water \\
& Biofuels & Drinking water \\
& & Air quality \\
& & Recent wildlife protection (except farm birds) \\
& & Waste \\
& & Renewables \\
& & Chemicals \\
& & Genetically modified organisms (GMOs) \\
& & Fracking \\
& & Environmental impact assessment (EIA) \\
& &
\end{tabular}

\section{MULTI-DIRECTIONAL EFFECTS}

Table 1 is designed to show the interaction between the UK and the EU in environmental policy in a bi-directional and bi-dimensional manner, to show that the impacts have not all been one way and have not been uniformly positive or negative, but rather a mix of both. ${ }^{4}$ In the campaigning and debate leading up to the EU referendum, the Remain side typically emphasized the ways in which the EU had been good for the UK environment and that leaving would therefore be harmful. This side of the argument is captured by the bottom right-hand box of Table 1 and the policy areas contained within, such as drinking water, bathing water and waste policy, where EU directives have undoubtedly led to significant improvements in UK standards. A number of Remainers, however, did also

eu-reform-green-brexit ('The most profound weakness of the EU, from the Green point of view, is that it is a super-sized top-down dogmatic project of endless industrial development and growth. It fosters the pointless carting of goods [over] enormous distances, and it smashes local resilience and selfreliance. Often well-intentioned environmental policies are outweighed at every turn by the more fundamental drivers of its bid to turn the whole of Europe into a paradise for (environmentally damaging) agribusiness and industry'). The Green Party itself was in favour of Remain (being more concerned with the threat of Brexit to the environmental acquis): Green Party, 'Natalie Bennett Unveils Our “Three Yeses” to Europe', 23 Jan. 2013, available at: https://www.greenparty.org.uk/news/ 2013/01/23/natalie-bennett-unveils-our-three-yeses-to-europe.

4 IEEP, 'Report on the Influence of EU Policies on the Environment', Aug. 2013, p. 1 (stressing a two-way relationship), available at: http://assets.wwf.org.uk/downloads/final_report_influence_of_eu_policies_ on_the_environment.pdf. 
mention the few EU policy areas in the bottom left-hand box that have not necessarily been environmentally beneficial for the UK, including in particular the Common Agricultural Policy (CAP) and the Common Fisheries Policy (CFP). ${ }^{5}$ The CAP, for example, has gone hand in hand with an intensification of agriculture and has been associated with, inter alia, a decline in previously common farmland birds and diffuse nitrate pollution of watercourses from fertilizers. ${ }^{6}$ In that respect, it can be argued that non-environmental EU policy ${ }^{7}$ has had as much, if not more, of an effect on the quality of the UK environment as dedicated environmental policy. An assessment of the effects of Brexit on the environment, therefore, should not be limited to a consideration of environmental law and policy alone.

Understandably in a referendum aimed at persuading UK voters, the effects of UK membership on the EU received less attention. However, in assessing the overall effects of Brexit on the environment, these effects - set out in the top half of Table 1 - also require careful consideration as part of a bi-directional assessment. Some have been positive. For example, the UK has driven the EU on climate change targets $^{8}$ and has encouraged the greening of the CAP. ${ }^{9}$ It was also instrumental in the design of the Integrated Pollution Prevention and Control (IPPC) industrial emissions regime, which later became the Industrial Emissions Directive. ${ }^{10}$ EU external policy on the environment has also been enhanced by UK input, especially in the area of climate change negotiations. Membership of the EU has given the UK more influence than it would otherwise have had - the UK gets the benefits of putting forward its own views but with the added weight of a larger bloc's platform to support them. ${ }^{11}$ Other effects, where the UK government has blocked or watered down EU

5 See also, e.g., biofuels, where EU policy has been questioned on environmental grounds both by those on the Leave side (see, e.g., dissenting report by P. Lilley, EAC, n. 1 above) and by the environmental movement (see, e.g., G. Monbiot, 'These Brexiters Will Grind Our Environment into the Dust', The Guardian, 20 July 2016, available at:https://www.theguardian.com/commentisfree/2016/jul/20/brexiters-make-britain-countryside-like-kansas).

6 Burns et al., n. 1 above, p. 37.

7 Although, of course, EU agricultural policy has for some time contained agri-environmental policy (albeit of questionable overall ambition).

8 IEEP, n. 4 above, pp. 7, 24; Burns et al., n. 1 above, p. 16.

9 Burns et al., n. 1 above, p. 38; Written Evidence of V. Gravey, C. Burns \& A. Jordan, submitted to the House of Commons (HC), EAC Inquiry, 'The Future of the Natural Environment after the EU Referendum' (Session 2016-17), Aug. 2016, para. 13, available at: http://data.parliament.uk/writte nevidence/committeeevidence.svc/evidencedocument/environmental-audit-committee/the-future-of-thenatural-environment-after-the-eu-referendum/written/35891.html.

10 Directive 2010/75/EU on Industrial Emissions (Integrated Pollution Prevention and Control) (recast) [2010] OJ L 334/17. EAC, n. 1 above, para. 22; cf. N. Haigh, EU Environmental Policy: Its Journey to Centre Stage (Routledge, 2016), pp. 197-203 (noting resistance to the British idea of a single permitting authority).

11 Burns et al., n. 1 above, p. 11; J. Gummer et al., 'Within the EU, Britain Can Take the Lead on Tackling Climate Change', The Guardian, 18 Apr. 2016, available at: https:/www.theguardian.com/environment/2016/apr/18/within-the-eu-britain-can-take-the-lead-on-tackling-climate-change; EAC, n. 1 above, paras 15-18; IEEP, n. 4 above, p. 7; R. Davis, 'Should Environmentalists Support the UK's Membership of the EU?', Energydesk Greenpeace, 17 Mar. 2016, available at: http://energydesk. greenpeace.org/2016/03/17/comment-brexit-environmentalists-support-uk-eu-membership. 
environmental legislation, have been negative. Recent examples include policies on air quality, ${ }^{12}$ fracking, ${ }^{13}$ energy efficiency, ${ }^{14}$ and soils. ${ }^{15}$

\section{A DYNAMIC RELATIONSHIP}

It is tempting to see the relationship between the EU and UK in static rather than dynamic terms across time. The temptation is thus to regard the UK as forever the laggard and the EU as always the leader. While it is not hard to see why prereferendum campaigning on the Remain side would take this stance, in reality the UK government's environmental credentials have fluctuated over time and across environmental policy areas. The EU's environmental record, too, changes according to the political complexion of the European Commission and Member State governments in the Council of Ministers. Some of the policy areas listed in Table 1 provide a good illustration of this. For example, the EU ETS could legitimately be placed in either the 'EU policy diluted' or the 'EU policy strengthened' box. Insofar as the UK pushed for this policy in the first place $^{16}$ and it has become regarded by many as a somewhat ineffective neoliberal instrument, ${ }^{17}$ it might legitimately be put in the negative top left-hand box. However, the UK has also been instrumental more recently in trying to strengthen the policy by restricting allowances, ${ }^{18}$ which could mean UK influence belongs more in the positive top right-hand box. Similarly, while the UK was an early advocate of nature conservation laws and was thus supportive of the Habitats Directive ${ }^{19}$ at the time of its inception, ${ }^{20}$ in recent years the UK government, arguably, has come to regard the Directive as a burdensome obstruction to development projects. ${ }^{21}$ As regards the EU's changing stance vis-à-vis the

12 A. Neslen, 'EU Dilutes Proposal to Halve Air Pollution Deaths after UK Lobbying', The Guardian, 3 June 2016, available at: https:/www.theguardian.com/environment/2016/jun/03/eu-dilutes-proposalhalve-air-pollution-deaths-uk-lobbying.

13 D. Carrington, 'UK Defeats European Bid for Fracking Regulations', The Guardian, 14 Jan. 2014, available at: https://www.theguardian.com/environment/2014/jan/14/uk-defeats-european-bidfracking-regulations.

14 EAC, n. 1 above, para. 23.

15 Department for Environment, Food \& Rural Affairs (DEFRA), 'Safeguarding our Soils: A Strategy for England', Sept. 2009, p. 3, available at: https:/www.gov.uk/government/uploads/system/uploads/ attachment_data/file/69261/pb13297-soil-strategy-090910.pdf; G. Monbiot, 'The Farming Lobby Has Wrecked Efforts to Defend Our Soil', The Guardian, 5 June 2014, available at: https://www.theguardian.com/environment/georgemonbiot/2014/jun/05/the-farming-lobby-has-wreckedefforts-to-defend-our-soil.

16 IEEP, n. 4 above, p. 25; Burns et al., n. 1 above, p. 16.

17 See, e.g., G. Winter, 'The Climate Is No Commodity: Taking Stock of the Emissions Trading System' (2010) 22(1) Journal of Environmental Law, pp. 1-25.

18 Burns et al., n. 1 above, p. 18.

19 Directive 92/43/EEC on the Conservation of Natural Habitats and of Wild Fauna and Flora [1992] OJ L 206/7.

20 Burns et al., n. 1 above, p. 138; House of Lords Select Committee on the European Union, Energy and Environment Sub-Committee, 'Brexit: Environment and Climate Change', 26 Oct. 2016, oral evidence of T. Hutchings (World Wildlife Fund), p. 22, available at: http://data.parliament.uk/writtenevidence/ committeeevidence.svc/evidencedocument/eu-energy-and-environment-subcommittee/brexit-environmentand-climate-change/oral/42398.pdf.

21 As opposed to ensuring sustainable development. For details of the government's negative view see, e.g., HM Treasury Autumn Statement 2011, para. 1.99; A. Neslen, 'Brexit Would Free UK from 
environment, the current Juncker-led EU Commission, for example, worried some environmentalists with its Better Regulation-based 'fitness check' of the Birds ${ }^{22}$ and Habitats Directives. $^{23}$

The dynamic nature of the EU-UK environmental relationship requires consideration not only of the past and present but also looking to the future. In the lead-up to the referendum, the future direction of the UK government's environmental policy was undoubtedly a cause for concern in some quarters. Anecdotally, many environmentally conscious voters appeared minded to vote Remain in part because of a fear that a Conservative government, which had previously referred to environmental issues as 'Green crap', ${ }^{24}$ would see Brexit as an opportunity to deregulate troublesome environmental 'red tape' ${ }^{25}$ Deregulation both in general and in relation to the environment specifically - also featured strongly in the Leave campaign. ${ }^{26}$ Nevertheless, the government's balance of competences review on the environment and climate change in the run-up to the referendum in general revealed no obvious clamouring for deregulation by environmental and industry stakeholders.${ }^{27}$ As for the government's own view, the Environmental Audit Committee (EAC) report made clear:

The Government's renegotiation of the UK's relationship with the EU did not explicitly include a reference to the environment. Mr Stewart, Minister at DEFRA, told us: 'We are not intending to renegotiate those directives. [...] The basic structure of the competences, the basic structure of European environmental law in relation to our Department I think is very close to what we think is sensible. It is what we would intend to do in the United Kingdom.' Lord Bourne, Minister at DECC, said, 'in this area of energy and climate change, the UK's interests are very much within a strong EU. [...] this area is not part of the renegotiation. We are very comfortable with the EU stance. ${ }^{28}$

Of course, while that was true of the pre-referendum government, no one knew what a post-Brexit government might look like. Many suspected that it might be led by pro-Brexit politicians on the right of the Conservative party, a number of whom had

“Spirit-Crushing” Green Directives, Says Minister', The Guardian, 30 May 2016, available at: https:/www.theguardian.com/politics/2016/may/30/brexit-spirit-crushing-green-directives-ministergeorge-eustice.

22 Directive 2009/147/EC on the Conservation of Wild Birds [2010] OJ L 20/7.

23 IEEP, n. 1 above, p. 20; European Commission, 'Fitness Check of the Birds and Habitats Directives', available at: http://ec.europa.eu/environment/nature/legislation/fitness_check/index_en.htm; see further V. Gravey, 'Nature Directives "Fit for Purpose”: A Turning Point for EU Policy Dismantling?', Environmental Europe? blog, 7 Dec. 2016, available at: http://environmentaleurope.ideasoneurope.eu/ 2016/12/07/naturealertrefit.

24 J. Garman, “"Green Crap”? Cameron's U-Turn on the Environment is Just as Shameful as Clegg's on Tuition Fees', The Independent, 21 Nov. 2013, available at: http://www.independent.co.uk/voices/ comment/green-crap-camerons-u-turn-on-the-environment-is-just-as-shameful-as-cleggs-on-tuitionfees-8954747.html.

25 See further L. Fisher, 'Sovereignty, Red Tape ... and the Environment', Political Studies Association (PSA) blog, 17 June 2016, available at: https://www.psa.ac.uk/insight-plus/blog/sovereignty-red-tape\% E2\% $80 \%$ A6and-environment.

26 On the environment see, e.g., Neslen, n. 21 above.

27 HM Government, n. 1 above.

28 EAC, n. 1 above, paras 56-7. 
climate-sceptic views and were unsympathetic to the environment more generally. To that extent, therefore, any deregulatory fear was potentially well founded. In the end, the fall-out from the referendum produced a new government led by a supposedly 'quiet Remainer' Prime Minister, with a leading Leave campaigner as Environment Secretary and with three prominent 'Brexiteer' ${ }^{29}$ members of the Cabinet tasked with negotiations on Brexit, including those relating to the environment. This government remained in power after a snap election in June 2017, albeit with a much reduced majority.

It may be too early to predict the government's ideological approach post-Brexit. However, in contemplating the impact of Brexit on the environment, political will is in any event only part of the equation. In practice, significant change in UK environmental policy seems unlikely for two reasons. Firstly, the policy literature tells us that path dependence from a relationship built up over many decades means that there will be a significant inclination towards maintaining the status quo. ${ }^{30}$ Secondly, even if historically embedded ways of doing things were easily undone at the best of times (which path dependence tells us they are not), Brexit represents far from the best of times. The overwhelming work pressure on the UK government, Parliament and the civil service in dealing with many of the procedural mechanics of Brexit - both centrally and arguably even more so within the devolved administrations of Wales, Scotland, and Northern Ireland - means that there is unlikely to be time to carry out a root-and-branch overhaul of environmental policy, at least in the short to medium term. This does not mean that no changes will occur. Firstly, the government is on record as stating that roughly one third of EU environment legislation will not be carried across via the European Union (Withdrawal) Bill ${ }^{31}$ (the statute designed to repeal the future legal authority of EU law in the UK while simultaneously carrying over the existing body of EU law onto the UK books). ${ }^{32}$ This is because there are some policies which, on leaving the EU, cannot easily take immediate legal effect through such a Bill. Obvious examples include legislation that requires some form of EU-level authorization process or involvement such as the REACH Regulation on chemicals ${ }^{33}$ and

29 Those on the Leave side in favour of Brexit have often been styled 'Brexiteers', with a nod to A. Dumas's The Three Musketeers.

30 B. Flynn, 'What a Difference a Vote Makes? Second Guessing British-EU Environmental Policy Interactions after Brexit', Environmental Europe? blog, 1 Aug. 2016, available at: http://environmentaleurope.ideasoneurope.eu/2016/08/01/difference-vote-makes-second-guessing-britisheu-environmental-policy-interactions-brexit. On path dependence see, e.g., P. Pierson, 'Increasing Returns, Path Dependence, and the Study of Politics' (2000) 94(2) The American Political Science Review, pp. 251-67; S. Krasner, 'Approaches to the State: Alternative Conceptions and Historical Dynamics' (1984) 16(2) Comparative Politics, pp. 223-46.

31 Available at: http://services.parliament.uk/bills/2017-19/europeanunionwithdrawal.html.

32 Oral evidence before the EAC Inquiry, 'The Future of the Natural Environment after the EU Referendum', 25 Oct. 2016 (Session 2016-17), Q. 327 (Andrea Leadsom MP), available at: http://data.parliament.uk/ writtenevidence/committeeevidence.svc/evidencedocument/environmental-audit-committee/thefuture-of-the-natural-environment-after-the-eu-referendum/oral/42022.html.

33 Regulation (EC) No. 1907/2006 concerning the Registration, Evaluation, Authorisation and Restriction of Chemicals (REACH), establishing a European Chemicals Agency, amending Directive 1999/45/EC and repealing Council Regulation (EEC) No. $793 / 93$ and Commission Regulation (EC) No. 1488/94 as well as Council Directive 76/769/EEC and Commission Directives 91/155/EEC, 93/67/EEC, 
the EU ETS. ${ }^{34}$ Anticipated changes are not driven by a deregulation rationale, but by the need to deal with the practical realities of transposition post-Brexit. ${ }^{35}$ Secondly, while a root-and-branch overhaul of environmental legal frameworks is unlikely, small-scale tinkering could occur and could still produce a major change in the effect of the law. For example, keeping the structures of the Birds ${ }^{36}$ and Habitats ${ }^{37}$ Directives in place but adopting minor changes to the conditions for derogation or to the interpretation of 'overriding reasons of imperative public interest' to justify development that harms a European Site (and what constitutes acceptable compensation) could significantly alter the impact of the law. ${ }^{38}$

For some time in the future after Brexit, then, a combination of path dependence and administrative pressures makes significant structural change to UK environmental policy unlikely, at least in areas that do not face Withdrawal Bill transposition difficulties. In that respect, UK policy in the short to medium term is not unlike that of the EU as far as ability to change is concerned. Although the EU is currently going through what might be characterized as a deregulatory phase in respect of its environmental policy, in practice the rate of change is not great: as the 2016 UK EAC report observed, given the need to secure agreement among many Member States, it is not easy to change EU environmental policy. ${ }^{39}$ Thus, notwithstanding the fundamentally dynamic nature of the UK and EU relationship, the rate of change should not be overplayed. The EU environmental acquis, albeit not immobile, is relatively stable. The UK capacity to change after Brexit, in turn, is perhaps more constrained in practice than some might expect.

\section{FUTURE RELATIONSHIP MODEL}

Article 50 of the Treaty on European Union (TEU) provides for a two-year negotiation period once the UK government has triggered the Brexit process by formally communicating its intention to leave, which it did at the end of March 2017. The aim is for the UK and the EU to come to an agreement within this two-year period, at which point the UK will cease to be an EU Member State. If such an agreement cannot be reached then, under Article 50 TEU, the UK will drop out of the EU at the end of the period, unless the other 27 Member States unanimously agree to an extension beyond two years. While any agreement arising from this process is

93/105/EC and 2000/21/EC, [2006] OJ L 396/1. See further EAC, 'The Future of Chemicals Regulation after the EU Referendum', 11 th Report of Session 2016-17, 29 Apr. 2017, HC 912, available at: https://publications.parliament.uk/pa/cm201617/cmselect/cmenvaud/912/912.pdf.

34 The Repeal Bill White Paper provides the example of Reg. 6(2)(b) of the Offshore Petroleum Activities (Conservation of Habitats) Regulations 2001, SI 2001/1754, which contains a requirement to obtain an opinion from the European Commission. This will require removal (and possible replacement with a UK body) via secondary legislation: Department for Exiting the European Union, 'Legislating for the United Kingdom's Withdrawal from the European Union', Cm 9446, 2017, p. 20.

35 House of Lords, European Union Committee, 12 th Report of Session 2016-17, 'Brexit: Environment and Climate Change', HL Paper 109, para. 58.

36 N. 22 above.

37 N. 19 above.

38 I am grateful to one of the anonymous referees for this point.

39 EAC, n. 1 above, paras 29-32. 
expected to include the terms of the 'divorce' - how resident EU citizens, EU staff pensions, existing UK budget contributions, assets, and so on are to be dealt with the extent to which it will also include the terms of the UK's future relationship with the EU remains less clear. There is a view that it may be impractical to cover both the divorce and the future relationship within the two-year negotiation period and that the future relationship will therefore be left to a separate 'mixed' agreement. In addition to European Parliament consent, this would require ratification by all EU Member States in accordance with their own constitutional arrangements (as with, for instance, the recent EU-Canada CETA bilateral trade deal). ${ }^{40}$ The UK government has nevertheless expressed the hope that an Article 50 TEU agreement would cover both issues. This would secure the twin advantages of requiring only qualified majority voting by the Council (and the consent of the European Parliament) for its approval and avoiding a damaging gap period during which, in the absence of a future relationship agreement or a transitional arrangement, the UK's relationship status with the EU could fall back on World Trade Organization (WTO) rules (and associated tariffs). The European Council, in contrast, has stated that it stands 'ready to engage in preliminary and preparatory discussions' on the future relationship agreement in the context of negotiations under Article 50 TEU, but only when it 'decides that sufficient progress has been made in the first phase towards reaching a satisfactory agreement on the arrangements for an orderly withdrawal'.41

Whatever legal form is finally adopted, the eventual model chosen for the UK's future relationship with the EU is likely to make a significant difference to whether Brexit turns out to be positive or negative for the environment. Since the referendum there has been much discussion of the nature of the potentially available models. The adjectives used to describe Brexit have been many and varied, including, for example, 'dirty' Brexit, 'clean' Brexit, and even 'red, white and blue' Brexit. However, most commentators have settled on the UK's options lying somewhere on a spectrum between 'hard' and 'soft' Brexit. ${ }^{42}$ A hard Brexit could take a variety of forms but is essentially one that would take the UK outside the single market and probably also the customs union. A soft Brexit would preserve full single market access and could involve the UK remaining a member of the European Free Trade Area (EFTA) and joining the European Economic Area (EEA) (the so-called 'Norway model').

40 Comprehensive and Economic Trade Agreement (CETA) between Canada and the EU and its Member States, 15 Feb. 2017, available at: http://ec.europa.eu/trade/policy/in-focus/ceta/ceta-chapterby-chapter.

41 European Council, 'European Council (Art. 50) Guidelines for Brexit Negotiations', 29 Apr. 2017, Press Release 220/17, available at: http://www.consilium.europa.eu/en/press/press-releases/2017/04/29euco-brexit-guidelines (emphasis added).

42 It should be noted that this spectrum was rejected by the Prime Minister, Theresa May, in her speech to the 2016 Conservative Party Conference: "There is no such thing as a choice between "soft Brexit" and "hard Brexit". This line of argument - in which "soft Brexit" amounts to some form of continued EU membership and "hard Brexit" is a conscious decision to reject trade with Europe - is simply a false dichotomy ... it is not going to [sic] a "Norway model". It's not going to be a "Switzerland model". It is going to be an agreement between an independent, sovereign United Kingdom and the European Union': 'Britain after Brexit: A Vision of a Global Britain', available at: http://press.conservatives.com/ post/151239411635/prime-minister-britain-after-brexit-a-vision-of. 
A slightly less soft variant would involve entering into sector-by-sector bilateral agreements with the EU (the so-called 'Swiss model').

If the UK were to adopt a Norway model based on EEA membership, then most existing EU environmental policy would remain in place, with the key exceptions being the Habitats ${ }^{43}$ and Birds ${ }^{44}$ Directives and the Bathing Water Directive. $^{45}$ Under such a model, policy areas with significant environmental implications, notably agriculture and fisheries, would also return to UK control. A Swiss-style soft Brexit would preserve much less of the EU environmental acquis. In the Swiss case, there has merely been some attempt at coordination between the EU ETS and the Swiss ETS. Switzerland also enjoys (paid) membership of the European Environment Agency. ${ }^{46}$ In the case of a hard Brexit followed by a Canada/CETA-style free trade agreement, there would not even be this minimal level of direct involvement in EU environmental policy institutions (although the CETA does provide for some cooperation on environmental issues ${ }^{47}$ ). In addition, the CETA largely preserves the right of each country to choose its own levels of environmental protection, ${ }^{48}$ subject to certain exhortations not to lower standards in a race to the bottom. ${ }^{49}$ Thus, if either a Swiss-style soft Brexit or a hard Brexit transpires, the landscape for UK environmental policy becomes less predictable than with the softer EEA Norway model, which preserves much of the status quo.

However, in terms of the impact of the UK's future relationship with the EU on the dynamics at play in Table 1, either a hard or a soft Brexit scenario removes the top left- and right-hand boxes from consideration. In neither scenario will the UK retain the ability to block or dilute proposed EU legislation that it does not like. On this basis, Brexit of either kind would (ceteris paribus) be positive for the stringency of EU environmental policy (and, under the Norway model therefore also for environmental policy in the UK, which would be obliged to implement it); ${ }^{50}$ nor, of course, will the UK be able to positively influence EU environmental policy.

Now, considering the inverse direction of influence represented in the bottom two boxes of Table 1, it should not be assumed that EU influence on UK environmental policy will disappear after Brexit, even on a hard Brexit model. The single market of the UK's large trading neighbour is bound to exert a considerable influence over its domestic policy. This is particularly true with regard to environmentally related

43 N. 19 above.

44 N. 22 above.

45 Directive 2006/7/EC concerning the Management of Bathing Water Quality [2006] OJ L 64/37.

46 Agreement between the European Community and the Swiss Confederation concerning the Participation of Switzerland in the European Environment Agency and the European Environment Information and Observation Network, available at: https://www.eda.admin.ch/dea/en/home/bilateraleabkommen/abkommen-umsetzung/abkommenstexte/umwelt.html.

47 CETA, n. 40 above, Arts 22.3 and 24.12.

48 Ibid., Art. 24.3.

49 Ibid., Art. 24.5.

50 M. Le Page, 'Green Lining? Five Ways Brexit Could Be Good for the Environment', New Scientist, 29 June 2016, available at: https://www.newscientist.com/article/2095482-green-lining-five-waysbrexit-could-be-good-for-the-environment. 
product standards ${ }^{51}$ (such as on vehicle emissions) ${ }^{52}$ as UK manufacturers will most probably wish to continue to export to the single market. ${ }^{53}$ There would inevitably be pressure to harmonize relevant UK standards with those of the EU. Hence, even after leaving the EU, the UK could still find itself in a position where its environmental policy is strengthened by the EU. However, for environmental and climate targets and associated process standards, the influence of competition from the single market could also be negative. If the EU adopts weaker standards than those of the UK, then the latter may find it hard to subject its own industries ${ }^{54}$ to unilateral stringent targets, which could harm their competitiveness when compared with the weaker EU rules facing their rivals. In this case, even after leaving the EU, the UK could still find itself in the bottom left box in Table 1, with its environmental policy weakened by the EU. Thus, even after a hard Brexit, the single market's continuing influence on UK environmental policy means that the UK will still be affected both positively and, potentially, negatively. However, regardless of whether a soft or hard Brexit is pursued, the scope for the UK to continue to influence EU environmental policy will be severely curtailed.

\section{CAUSATION}

As Burns and her co-authors note, ${ }^{55}$ it is notoriously difficult to state with any degree of certainty that improvements to UK environmental quality were caused by EU membership. Some changes may have happened in time in any event, even without EU influence (as a result of, for instance, policy convergence), and it is not always possible to disentangle multiple causes of environmental change (for example, separating the impact of EU policy from improvements to environmental quality caused by deindustrialization, or other economic changes such as the 'dash to gas').

When assessing impact, time has a key bearing on assessing whether leaving the EU is positive or negative for the environment. Before the referendum, much was made of the significant positive impact the EU has had historically on UK environmental policy. Take the Bathing Water Directive ${ }^{56}$ as an example. Many rightly point to the impact of this instrument, along with the Urban Waste Water Treatment Directive, ${ }^{57}$ on the quality of UK bathing waters that were previously severely polluted with untreated sewage effluent. However, in trying to establish whether, on balance, the EU has been positive for UK environmental policy, we cannot easily assess whether the UK would, in time, have taken action itself in these areas in any event. All we can safely conclude is that, at the time, the UK was not

51 As well as, in some instances, process standards (where the EU exerts extraterritorial control over process standards in relation to products that want access to the single market): see J Scott, 'Extraterritoriality and Territorial Extension in EU Law' (2014) 62(1) American Journal of Comparative Law, pp. 87-125.

52 Directive 2007/46/EC Establishing a Framework for the Approval of Motor Vehicles [2007] OJ L 263/1.

53 IEEP, n. 1 above, p. 7; Heyvaert \& Čavoški, n. 1 above, p. 125.

54 Including agriculture: Gravey et al., n. 9 above, para. 13.

55 Burns et al., n. 1 above, pp. 8-9 and 135-6.

56 N. 45 above.

57 Directive 91/271/EEC concerning Urban Waste Water Treatment [1991] OJ L 135/40. 
acting and EU policy pressured it into doing so. Environmental impact assessment (EIA) provides a further example, including evidence of some prior UK action in this

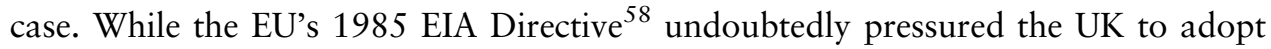
EIA as a procedural mechanism within land-use planning decision making, the UK had in fact issued a report that considered EIA in $1977 .{ }^{59}$ In doing so, it is likely to have taken inspiration from the United States' (US) 1969 National Environmental Policy Act. ${ }^{60}$ However, progress in implementing the report's recommendations was very slow and was eventually overtaken by the requirements of the EIA Directive. ${ }^{61}$ Although the UK may eventually have acted on EIA on its own accord, it was hostile to the proposed directive, which it managed to water down. ${ }^{62}$ Even then, as Jordan notes, 'left to its own devices, Britain would almost certainly have adopted a much more informal and voluntary system than the one promoted by the EU' and with a narrower scope in terms of projects caught by the regime. ${ }^{63}$

Moving away from the historical, there is the separate question of whether the EU remains a necessary current pressure for the UK in relation to environmental policy. With bathing water the answer is that it is less called for today ${ }^{64}$ in that over $96 \%$ of UK beaches are now of sufficient quality or above. ${ }^{65}$ That said, there is no room for complacency as the UK remains second bottom in the EU in terms of the rates of bathing waters with poor quality. ${ }^{66}$ Air quality is probably the most obvious area of environmental law where EU-based pressure today still plays a significant role. The number of lives lost as a result of $\mathrm{NO}_{2}$ pollution is one of the highest in the EU, ${ }^{67}$ and $\mathrm{EU}$ law has been instrumental in the court-based efforts of non-governmental organization (NGO) ClientEarth to apply pressure on the UK government to improve air quality. ${ }^{68}$

It is also worth pausing to consider the often mentioned 'fall-back' impacts of international law in terms of the causal relation between EU influence and UK impact in Table 1. Areas where UK environmental policy has been strengthened by the EU, identified in the bottom right box of the table, would not automatically be endangered

58 Directive 85/337/EEC on the Assessment of the Effects of Certain Public and Private Projects on the Environment [1985] OJ L 175/40.

59 Scottish Natural Heritage (SNH), 'Environmental Assessment Handbook', Annex 6, available at: http://www.snh.org.uk/publications/on-line/heritagemanagement/EIA/annex6.shtml.

60 National Environmental Policy Act of 1969, 42 U.S.C. $\S 4332, \S 102$.

61 SNH, n. 59 above.

62 A. Jordan, The Europeanization of British Environmental Policy: A Departmental Perspective (Palgrave Macmillan, 2002), p. 180.

63 Ibid., p. 181; see also p. 186.

64 IEEP, n. 4 above, para. 4.3.1.

65 European Environment Agency, 'European Bathing Water Quality in 2016', Report No. 5/2017, 23 May 2017, available at: https://www.eea.europa.eu/publications/european-bathing-water-qualityin-2016. This is compared with only 27\% in 1990: DEFRA, Environment Agency \& Rory Stewart MP, 'England's Bathing Water Results 2015', 5 Nov. 2015, available at: https:/www.gov.uk/government/ news/englands-bathing-water-results-2015.

66 European Environment Agency, ibid.

67 European Environment Agency, 'Air Quality in Europe - 2016 Report', Report No. 28/2016, 23 Nov. 2016, p. 59, available at: https://www.eea.europa.eu/publications/air-quality-in-europe-2016.

68 From a line of cases see, e.g., ClientEarth (No. 2) v. Secretary of State for the Environment, Food and Rural Affairs [2016] EWHC 2740 (Admin). 
by the UK's departure from the EU. This is because in a number of areas the UK is subject to obligations under international environmental law that will provide fall-back protection, ${ }^{69}$ albeit typically not as comprehensive or anywhere nearly as effectively enforceable as EU law. It cannot therefore be said that but for EU membership those areas of environmental policy would be completely jeopardized, because the UK's international obligations will still exert a protective effect, albeit a lesser one.

\section{DEVOLUTION}

The current section on devolution assumes that the UK will have a common, single future relationship model with the EU, as opposed to one that varies internally with, for example, Scotland remaining an EU member, or perhaps a member of the single market, while the rest of the UK leaves. ${ }^{70}$ To the extent that environmental policy is a devolved matter in the UK, there are currently some differences in policy and performance across the various constituent parts of the UK, ${ }^{71}$ but these differences are kept in check to a considerable degree by common EU standards across many areas. ${ }^{72}$

Linking this back to the discussion above regarding the effects of Brexit on the UK environment, such effects are also likely to depend on the possible greater divergence between, for example, Scottish and English environmental law that leaving the EU might produce. The scope for such divergence depends firstly on the extent to which repatriated environmental competence is exercised centrally by Westminster or is devolved. There is obviously much greater scope for divergence in the latter scenario.

69 A good example of this is provided by the Aarhus Convention (Convention on Access to Information, Public Participation in Decision-making and Access to Justice in Environmental Matters, Aarhus (Denmark), 25 June 1998, in force 30 Oct. 2001, available at: https:/www.unece.org/fileadmin/DAM/ env/pp/documents/cep43e.pdf). Others include the OSPAR Convention (Convention for the Protection of the Marine Environment of the North-East Atlantic, Paris (France), 22 Sept. 1992, in force 25 Mar. 1998, available at: https://www.ospar.org/convention/text) and the Bern Convention (Convention on the Conservation of European Wildlife and Natural Habitats, Bern (Switzerland), 19 Sept. 1979, in force 1 June 1982, available at: http://www.coe.int/en/web/bern-convention). These are all mixed agreements, where the UK is a party in its own right as well as the EU. Such agreements (unlike those which lie in the exclusive competence of the EU) are likely to remain binding on the UK post-Brexit without the need for renegotiation, although not everyone takes this view: see J. Newbigin, 'International Environmental Law After Brexit', UK Environmental Law Association (UKELA), 25 May 2017, available at: https://www.ukela.org/blog/Brexit-Task-Force/International-environmental-lawafter-Brexit.

70 The Scottish government expressed a desire to remain part of the EEA: Scottish Government, Scotland's Place in Europe (2016), para. 85. However, any form of unique continuing relationship for Scotland seems a remote prospect because of the likelihood of hostility from other Member States, such as Spain, wary that such an arrangement might encourage their own separatist movements.

71 See, e.g., divergent policy on genetically modified organisms (GMOs) between Scotland and England (S. Carrell, 'Scotland to Issue Formal Ban on Genetically Modified Crops', The Guardian, 9 Aug. 2015, available at: https://www.theguardian.com/environment/2015/aug/09/scotland-to-issue-formal-ban-ongenetically-modified-crops); and on waste law and the circular economy (S. Holmes, 'Brexit and Environmental Law' (2016) 28(1) Environmental Law and Management, pp. 37-41, at 40-1).

72 C. Reid, 'Taking Back Control From Brussels: But Where To?', OUPblog, 7 Nov. 2016, available at: http://blog.oup.com/2016/11/brexit-uk-eu-brussels: 'At a less dramatic level, the removal of the need to comply with EU law will risk greater divergence within the UK in relation to environmental law'. See also Heyvaert \& Čavoški, n. 1 above, p. 123. Cf. GMOs where recent reforms have left much more discretion in the hands of Member States in relation to cultivation of GM crops on their territory: see, e.g., M. Dobbs, 'Attaining Subsidiarity-based Multilevel Governance of Genetically Modified Cultivation?' (2016) 28(2) Journal of Environmental Law, pp. 245-73. 
Whether such divergence would be worse for the environment than the pre-Brexit position is hard to predict; it is at least conceivable that all of the devolved governments and England would improve environmental quality. Equally possible - although they have nearly all promised otherwise ${ }^{73}$ - is that we could see one or more of the component parts of the UK loosen its/their environmental controls from a Brexit baseline, while others (and the EU) maintain or raise theirs. Alternatively, and perhaps as likely, is that although standards might not fall below the Brexit baseline, some parts of the UK would climb beyond these while others would allow them to stagnate. ${ }^{74}$

\section{ENFORCEMENT}

It would be a mistake to examine the potential environmental impacts of leaving the EU only with reference to a checklist of policy sectoral winners and losers. As noted by Lee, ${ }^{75}$ one of the major gaps that could be opened up by leaving is an enforcement governance gap. Membership of the EU brings with it procedural reporting obligations $^{76}$ on Member States and exposure to various enforcement mechanisms ${ }^{77}$ to ensure compliance with EU environmental provisions. This broader architecture is an essential component of the effectiveness of environmental governance in the UK. Some existing UK laws, notably the Climate Change Act 2008, do have their own institutional, reporting and enforcement arrangements, which could serve as a source of inspiration when constructing a postBrexit enforcement system. ${ }^{78}$ However, these arrangements fall short of the political and legal accountability mechanisms that the UK has become used to through EU membership. In the end, leaving gives rise to concern not just about the future quality of environmental legislation, but also about the opportunities for citizens and NGOs to

73 In their respective White Papers on Brexit, the current Scottish government has committed to 'maintaining, protecting and enhancing' the environment (n. 70 above, para. 93) and the Welsh government 'at a minimum, to maintaining current standards in respect of air and water quality, emissions and environmental protection (Welsh Government, Securing Wales' Future: Transition from the European Union to a New Relationship with Europe (2017), p. 29). In its Brexit White Paper, the UK Conservative government similarly states that it is committed to ensuring we become the first generation to leave the environment in a better state than we found it' (HM Government, The United Kingdom's Exit from and New Partnership with the European Union (2017), Cm 9417, para. 8.41). However, this should be contrasted with the unwillingness of government ministers, when appearing before the EAC and having been asked seven times, to commit to retaining EU air quality limits following Brexit (Baroness Jones \& Baroness Parminter, 'Green Brexit: Safeguarding Britain's Environment', Politics Home, 16 Jan. 2017, available at: https://www.politicshome.com/news/uk/environment/house/82418/ green-brexit-safeguarding-britains-environment.

74 I.e., there is a risk that in some areas the Withdrawal Bill's transposition of EU environmental law may produce 'zombie' legislation that sits dustily on the shelf, poorly enforced and without being updated in accordance with developing scientific standards: EAC, 'The Future of the Natural Environment after the EU Referendum', 6th Report of Session 2016-17, HC 599, para. 39.

75 'Brexit: Environment and Climate Change', n. 20 above, oral evidence of M. Lee, answers to Q. 9.

76 E.g. Directive 2000/60/EC Establishing a Framework for Community Action in the Field of Water Policy [2000] OJ L 327/1 (Water Framework Directive), Art. 15 (duty to report on river basin management plans to the Commission).

77 Both public, via Art. 258 of the Treaty on the Functioning of the European Union (TFEU) (infringement proceedings by the Commission), and private (in national courts, relying on doctrines such as direct effect).

78 'Brexit: Environment and Climate Change', n. 20 above, oral evidence of M. Lee, answers to Q. 9. 
hold the government to account. Domestic judicial review will, of course, still be available, ${ }^{79}$ but civil society could lose its ability to hold government to resilient environmental standards. One of the core strengths of EU environmental law is the idea that it represents a credible long-term commitment, which cannot be changed at the whim of individual governments just because, for example, they are struggling to meet existing targets.

The extent to which Brexit would produce an enforcement gap depends in large measure on the future relationship model that is eventually adopted. This is true of both public enforcement by the Commission and private enforcement by individuals in the national courts. With a hard Brexit, all of this would go. Public enforcement under a soft Brexit Norway/EEA model involves a surveillance authority with similar supervisory powers to the Commission. However, this arrangement lacks the ability to impose financial penalties on recalcitrant states. ${ }^{80}$ The only recourse consists of a second appearance before the EFTA Court. This same arrangement applied in the EU before the introduction of penalty payments and lump sums, and was considered unsatisfactory. As for private enforcement, in EEA law there is still indirect effect $^{81}$ and state liability, ${ }^{82}$ but there is no direct effect ${ }^{83}$ and no principle of supremacy. ${ }^{84}$ These latter two doctrines, in particular, have been central to the ability of citizens and NGOs to mobilize EU law effectively in their national courts.

\section{BREXIT, SOVEREIGNTY AND CONTROL}

While the first part of this article considered the potential practical consequences of Brexit for environmental policy and quality - principally in the UK but also more broadly within the EU - the second part examines the normative consequences of Brexit for issues of sovereignty and control. The principle of subsidiarity - which involves consideration of and justification for which geographical level of action is best suited to particular areas of policy - is very much at the heart of these debates.

Arguably the most powerful narrative put forward by the Leave side during the referendum campaign was one of 'taking back control' and restoring sovereignty to the $\mathrm{UK}^{85}$ - both having supposedly been lost to 'unelected bureaucrats' in 'Brussels'.

79 Although the House of Lords European Union Committee report (n. 35 above) noted witness concerns that 'existing domestic judicial review procedures may be inadequate and costly' (para. 84). Improved access to justice is thus likely to be a necessity post-Brexit. Concerns have also been raised about the Withdrawal Bill's lack of implementation of principles such as the precautionary and polluter pays principles, which have been used in judicial review: S. Laville, 'UK Withdrawal Bill "Rips the Heart out of Environmental Law", Say Campaigners', The Guardian, 17 Oct. 2017, available at: https://www.theguardian.com/environment/2017/oct/17/uk-withdrawal-bill-rips-the-heart-out-ofenvironmental-law-say-campaigners.

80 R. Macrory, 'Brexit Unlikely to Give UK Free Rein over Green Laws', ENDS Report 499, Sept. 2016, pp. 22-3, at 22; Burns et al., n. 1 above, pp. 90, 95.

81 Case E-4/01 Karl K. Karlsson v. The Icelandic State [2002] EFTA Ct. Rep. 240, para. 28.

82 Ibid., paras 29-33.

83 Ibid., para. 28.

84 Case E-1/07 Criminal Proceedings against A [2007] EFTA Ct. Rep. 246, paras 40-1.

85 E. Fisher \& J. Harrison, 'Beyond the Binary: Brexit, Environmental Law, and an Interconnected World', OUPblog, 19 Sept. 2016, available at http://blog.oup.com/2016/09/binary-brexit-environmental-law; 
While the key policy area in which many on the Leave side wished to regain control from the EU was undoubtedly immigration, with environmental policy much further down the list, ${ }^{86}$ it is nevertheless worth exploring what implications this narrative might have for the latter.

\subsection{Transboundary Environmental Problems}

It has become something of a truism that the environment is an area where individual state sovereignty on its own is often powerless to achieve desired environmental outcomes. The environment typically does not respect national borders and, hence, states must act together to see results. This is a long-standing element within the academic literature on the environment and subsidiarity: supranational-level action on transboundary environmental problems is justified because one state acting alone cannot tackle an environmental problem without other states also cooperating. ${ }^{87}$ Scandinavian acid rain in the 1970 s-80s is often given as an example: it was no use, for example, Sweden acting on its own on acid emissions if the UK's tall power station chimneys were largely responsible for the damage caused. Not surprisingly then, in the end, EU-level action was taken to tackle this problem via the Large Combustion Plant (LCP) Directive, ${ }^{88}$ which imposed limits on acid gas emissions from power stations. What this example shows is that, in relation to transboundary problems like air pollution, state sovereignty in isolation gets one nowhere and that supranational EU-level coordination is likely to produce more effective pooled sovereignty and control.

\subsection{International Law Obligations}

If Brexit was about regaining sovereignty, a counter-narrative occasionally heard on the Remain side was that the Leave vision of 'pure', untrammelled sovereignty was a myth, in part because the UK would, after Brexit, remain subject to binding international law obligations. ${ }^{89}$ These involved the UK voluntarily constraining its sovereignty in order to achieve collective action goals, in much the same way as it had done by joining the EU. Reference to these continuing obligations has since become a common feature of the emerging commentary on Brexit and the environment. However, this argument is something of a

S. Weatherill, 'Why We Need the European Union', OUPblog, 20 June 2016, available at: http://blog.oup. com/2016/06/european-union-control.

86 Although cf. Neslen, n. 21 above.

87 See, e.g., C Hilson, Regulating Pollution (Hart, 2000), Ch. 3; M. Lee, EU Environmental Law, Governance and Decision-Making (Hart, 2014), pp. 20-1.

88 Directive 2001/80/EC on the Limitation of Emissions of Certain Pollutants into the Air from Large Combustion Plants [2001] OJ L 309/1, replacing Directive 88/609/EEC. The Directive has now been superseded by the Industrial Emissions Directive, n. 10 above. There was also international law coordination, considered further below.

89 A point also made by, e.g., D. French, 'Alternate Realities: Brexit and Pokémon', OUPblog, 10 Oct. 2016, available at: http://blog.oup.com/2016/10/brexit-pokemon-go-law; Reid, n. 72 above; and Fisher \& Harrison, n. 85 above. 
double-edged sword for environmentalist Remainers. While it rightly picks apart the myth that Brexit will return the UK to a land of 'year zero' unrestrained sovereignty, ${ }^{90}$ at the same time it undermines an argument that any action transcending the national level must necessarily emanate from the EU. Indeed, no state can successfully act alone on many environmental issues, and sovereignty must often be constrained in concert with others, but this can be done internationally and not just supranationally. The Birds Directive ${ }^{91}$ provides a good example. While very much focused, again, on the transboundary issue of migratory wild birds, which can only be adequately protected by states acting together, the Council of Europe Bern Convention ${ }^{92}$ and the Convention on the Conservation of Migratory Species of Wild Animals ${ }^{93}$ also provide important international law protection for migratory wild birds. The 1979 Convention on Long-Range Transboundary Air Pollution ${ }^{94}$ - introduced to tackle acid rain across Europe and which preceded the EU LCP Directive ${ }^{95}$ - is another example. ${ }^{96}$ To be sure, there are some additional advantages to supranational-level action over the international: EU rules tend to be more tightly framed than their international equivalents with concrete timetables for expected compliance, and they also benefit from more effective mechanisms for enforcement. ${ }^{97}$ Nevertheless, the point remains, at least in part. In any event, as French has noted, after Brexit UK environmental lawyers can be expected to turn their attention much more closely to all relevant international law instruments. ${ }^{98}$ Future research should look, in particular, at the gaps between EU law provisions and their supposedly equivalent international law counterparts. ${ }^{99}$ The UK courts, too (aided by creative NGOs and their lawyers), might be expected to play a role in ensuring that international law obligations can be appropriately enforced. ${ }^{100}$

90 As Scotford notes, '[i]f we are to think again about what standards we want to subscribe to as a nation and how to enforce these, this does not happen in a vacuum of legal development and expertise once we leave the European Union': E. Scotford, 'Air Quality Law in the United Kingdom at a Crossroads', OUPblog, 3 Oct. 2016, available at: http://blog.oup.com/2016/10/airquality-law-environment/\#sthash.Hq1ROMWO.QoyeWqC9.dpufhttp://blog.oup.com/2016/10/ air-quality-law-environment.

91 Directive 2009/147/EC on the Conservation of Wild Birds [2010] OJ L 20/7.

92 N. 69 above.

93 Bonn (Germany), 23 June 1979, in force 1 Nov. 1983, available at: http://www.cms.int/en/conventiontext.

94 Geneva (Switzerland), 13 Nov. 1979, in force 16 Mar. 1983, available at: https://www.unece.org/ fileadmin/DAM/env/lrtap/full\%20text/1979.CLRTAP.e.pdf.

95 N. 88 above.

96 Scotford, n. 90 above; see also Haigh, n. 10 above, pp. 49-51.

97 See also, e.g., Haigh (n. 10 above, pp. 50-1), who makes this point when arguing in favour of the LCP Directive, n. 88 above. However, the point is principally true of old governance-style EU directives. New governance measures, such as the proposed EU Directive on the Promotion of the Use of Energy from Renewable Sources (recast) (COM(2016) 767 final), offer a less impressively robust scope for enforcement.

98 French, n. 89 above. See also Reid, n. 72 above, who notes that ' $[\mathrm{t}]$ he extent of such treaty obligations can be easily overlooked since in recent decades the measures needed to give effect to them have often been introduced into the UK through EU law'.

99 UKELA is due to produce an international law mapping report later in 2017, see: https://www.ukela. org/brexitactivity.

100 See Macrory, n. 80 above, for suggestions on this. 


\subsection{UK Devolution Arrangements}

If EU-level supranational coordination on the environment falls away, then what is to fill the gap? Is there then a justification for centralized or coordinated environmental action at the UK level, in line with a principle of subsidiarity similar to that which animated EU-level environmental action itself, ${ }^{101}$ to deal with issues that the devolved parts of the UK cannot satisfactorily address on their own? The question arises because the environment is currently a devolved matter, where competence is effectively shared with the EU. After a hard Brexit, does repatriated EU competence over the environment similarly become devolved to become the exclusive competence of Scotland, Wales and Northern Ireland, or should at least some of it be centralized and competence be shared with Westminster ${ }^{102}$ This issue is all the more pressing where no equivalent international law fall-back exists to provide a direct replacement for EU law. ${ }^{103}$

The difficulty that centralized Westminster control faces is one of wariness by the devolved nations, whose sovereignty over environmental policy and other areas was hard-won through the devolution settlements. ${ }^{104}$ While repatriation of EU competence to Westminster would not involve a loss of existing sovereignty, devolved administrations are nevertheless understandably reluctant to replace the old EU master with a new, Westminster, version. ${ }^{105}$ This reluctance may arise from the potential for Westminster to ultimately allow less discretion in implementation than that provided by the EU system, and also for it to be more capriciously deregulatory, again in contrast to the slow pace of change we have come to associate with mature EU environmental law. The various Brexit White Papers provide an interesting insight into the matter. The Scottish and Welsh documents both effectively claim a presumption in favour of full devolution in already devolved areas like environmental policy, with their consent needed for central pooling, in what would need to be a new joint arrangement. ${ }^{106}$ The central UK and Welsh governments recognize a clear need for some form of arrangement where there is a risk of fragmenting the UK's internal

101 See Hilson, n. 87 above, Ch. 3, and Lee, n. 87 above, pp. 9-15.

102 This question is implicit in the title of Colin Reid's blog, n. 72 above: 'Taking Back Control From Brussels: But Where To?'.

103 Even where international law is in place, policing divergence across the various constituent administrations of the UK, so that the UK as a whole does not breach its obligations under that law, may be harder than with reference to EU law: see Reid, n. 72 above.

104 See Joint Statement by First Minister of Scotland, Nicola Sturgeon, and First Minister of Wales, Carwyn Jones in response to the introduction of the European Union (Withdrawal) Bill, 13 July 2017, available at: https://news.gov.scot/news/eu-withdrawal-bill ('We ... recognise that common frameworks to replace EU laws across the UK may be needed in some areas. But the way to achieve these aims is through negotiation and agreement, not imposition. It must be done in a way which respects the hard-won devolution settlements').

105 See, e.g., S. Lewis, Plaid Cymru Welsh Assembly Member, Welsh Assembly, The External Affairs and Additional Legislation Committee, 'Leaving the European Union: Implications for Wales Environment and Marine', 31 Oct. 2016, paras 151-2, available at: http://www.senedd.assembly. wales/documents/s55521/31\%20October\%202016.pdf; M. Dickie, 'Theresa May Takes Hard Line on SNP Demand for Special Brexit Deal', Financial Times, 3 Mar. 2017, available at: https://www.ft.com/ content/dca43e96-0007-11e7-96f8-3700c5664d30.

106 Welsh Government, n. 73 above, pp. 26-7; Scottish Government, n. 70 above, para. 9(c). 
market. ${ }^{107}$ This takes us back to subsidiarity and the various justifications for central control over the environment. Preserving an internal UK market from non-tariff barriers to trade forms one key justification for the central harmonization of standards. The definition of waste is an example of a case where the adoption of a common, UK-wide standard would be justified on this ground. Of course, since the UK exports a large amount of domestic waste to the rest of the EU in the form of refuse-derived fuel, this may well be an area where the UK chooses not to diverge from the EU definition. As the UK Environmental Law Association (UKELA) Waste Working Party observed:

It could, in theory, be possible to have one definition for waste that was traded only nationally within England and Wales while still applying the EU and Basel Convention definitions for waste exports. Would this result in a greater or lesser regulatory burden to industry? ${ }^{108}$

In principle, it would also be possible to have different definitions of waste within the UK. Nevertheless, this too is unlikely to prove attractive in terms of legal certainty and ease of trading for businesses operating across the UK's own internal market. Industry would hardly welcome having separate definitions for different jurisdictions within the UK. It would therefore require some form of UK regulatory governance framework to deliver an agreed definition of waste - whether this is one that matches the EU definition, or a common UK definition. Questions of waste are partly covered by international law (the Basel Convention on the Control of Transboundary Movements of Hazardous Wastes and their Disposal ${ }^{109}$ ), but its definition of waste rather unhelpfully for present purposes - links back to national law ${ }^{110}$ and applies only to exports. In that sense it cannot directly replace EU law.

While crafting a common UK definition of waste, and potentially also streamlining it with the EU definition, may be considered on the basis of a product-type, trade justification, another typical subsidiarity justification for federal-level action on the environment relates to averting unfair competition between states in a race to the bottom on standards. For example, what if, in the absence of the EU Industrial Emissions Directive, ${ }^{111}$ England decided to apply lower standards than those

107 'We recognise that in some cases, in the absence of EU frameworks which provide an element of consistency across the UK internal market, it will be essential to develop new UK-wide frameworks to ensure the smooth working of the UK market' (Welsh Government, n. 73 above, p. 26); 'We must also recognise the importance of trade within the UK to all parts of the Union ... So our guiding principle will be to ensure that - as we leave the EU - no new barriers to living and doing business within our own Union are created. We will maintain the necessary common standards and frameworks for our own domestic market' (HM Government, n. 73 above, para. 3.6). See also the Repeal Bill White Paper, n. 34 above, paras 4.2-4.3.

108 UKELA, 'Brexit: Implications of the UK Leaving the European Union: Waste Management', e-law, Mar.-Apr. 2016, pp. 17-21, at 17 and 19, available at: https://www.ukela.org/elaw-newsletterarchive.

109 Basel (Switzerland), 22 Mar. 1989, in force 5 May 1992, available at: http://www.basel.int/Portals/4/ Basel\%20Convention/docs/text/BaselConventionText-e.pdf.

110 Art. 2(1) states: "Wastes" are substances or objects which are disposed of or are intended to be disposed of or are required to be disposed of by the provisions of national law' (emphasis added). That said, Art. 2(4) does provide a definition of disposal ('any operation specified in Annex IV').

111 N. 10 above. 
applicable in the devolved administrations, hoping to make itself more attractive to investment through lower pollution control costs? Would this justify a common set of UK BREF-type ${ }^{112}$ standards to avoid this unfair and environmentally harmful competition? Again, there is no obvious single international law replacement for the EU Industrial Emissions Directive. What of possible devolved administration concerns over central control on race-to-the-bottom grounds? One way of meeting these would be to set only minimum standards centrally. These would act as a floor, with the devolved administrations and England then free to choose their own standards above this level, but unable to go below it. ${ }^{113}$ Such a floor might usefully be set at the level of existing EU standards. This approach would have much in common with EU law, which similarly typically allows Member States to adopt stricter measures (a point returned to again later).

A third major subsidiarity-based justification for centralized action on the environment applies when transboundary issues are involved, such as cross-border pollution or wildlife migration. In a UK context, the question arises of precisely what form such centralized control should take. For air pollution and migratory species which potentially range over large distances, central standards are likely to be justified. For water pollution, while a common set of standards can be justified at EU level because numerous cross-border watercourses transverse many continental countries, the UK situation involves much smaller numbers. This means that, instead of a centralized UK framework that draws up common regulatory standards across the various jurisdictions within the UK, one could instead seek to coordinate literally only at the borders.

As things stand, cross-border rivers within the UK (such as the Tweed between Scotland and England) are dealt with by legislation which seeks to coordinate the work of the respective environment agencies to achieve the river basin approach required by the EU Water Framework Directive. ${ }^{114}$ However, this cross-border cooperation currently happens towards the achievement of common water quality standards laid down in the Directive. After Brexit, water quality goals within the UK might start to diverge. Maintaining common standards across the UK might still be justified on race-to-the-bottom, competition grounds, so that industry and farming do not face different ambient quality targets that will inevitably lead to different emissions standards and controls on diffuse pollution, but not on the grounds of controlling cross-border pollution. After all, the various national environment agencies within the UK could simply coordinate, on cross-border rivers only, to ensure that stricter standards are not compromised by those of their neighbour.

Rivers that cross from the UK into another EU Member State (such as the Shannon into Ireland) would also be affected by Brexit. These are currently dealt with under the Water Framework Directive as International River Basin Districts, requiring

\footnotetext{
112 Best available technique reference documents; see further at: http://eippcb.jrc.ec.europa.eu/reference.

113 Suggested by C. Burns in her oral evidence to the Welsh Assembly, n. 105 above, para. 131 (and see further oral evidence by Burns et al., paras 137-9, 153, 161-2).

114 N. 76 above. The Water Environment (Water Framework Directive) (Solway Tweed River Basin District) Regulations 2004, SI 2004/99.
} 
coordination between the Member States to achieve the Directive's goals. ${ }^{115}$ On Brexit, Northern Ireland would no longer be part of an EU Member State and would hence be subject to treatment by Ireland under Article 3(5) of the Directive, which states:

Where a river basin district extends beyond the territory of the Community, the Member State or Member States concerned shall endeavour to establish appropriate coordination with the relevant non-Member States, with the aim of achieving the objectives of this Directive throughout the river basin district. Member States shall ensure the application of the rules of this Directive within their territory.

Such coordination could in theory become more difficult given that Northern Ireland would no longer be subject to the requirements of the Directive and might end up with different standards. However, the Irish river example is unlikely to give rise to severe problems because of the United Nations Convention on the Law of the NonNavigational Uses of International Watercourses (Watercourses Convention), ${ }^{116}$ to which the UK and Ireland are both signatories. Article 21(3) states:

Watercourse states shall, at the request of any of them, consult with a view to arriving at mutually agreeable measures and methods to prevent, reduce and control pollution of an international watercourse, such as: (a) Setting joint water quality objectives and criteria; (b) Establishing techniques and practices to address pollution from point and non-point sources; (c) Establishing lists of substances, the introduction of which into the waters of an international watercourse is to be prohibited, limited, investigated or monitored.

In the Scottish example in contrast, the Watercourses Convention would not apply because it applies only between states and not to devolved nations within states. However, some very similar form of cross-border cooperation would be needed.

\subsection{New Governance and Multilevel Governance}

'New governance', a key strand of practice and scholarship within EU law and politics during the previous decade, ${ }^{117}$ is also worth considering in relation to issues of control and sovereignty. As Fisher and Harrison have suggested, there is a danger in seeing Brexit and environmental sovereignty in strictly binary terms, with control and sovereignty either completely preserved or completely lost. ${ }^{118}$ While a large part of the original EU environmental acquis was very much aimed at uniformity across Member States, with centralization of power at EU level in order to achieve it, this

115 Water Framework Directive, n. 76 above, Art. 3(3)-(4).

116 New York (NY, US), 21 May 1997, in force 17 Aug. 2014, available at: http://legal.un.org/ilc/texts/ instruments/english/conventions/8_3_1997.pdf.

117 See, e.g., J. Scott \& D. Trubek, 'Mind the Gap: Law and New Approaches to Governance in the European Union' (2002) 8(1) European Law Journal, pp. 1-18; G. De Búrca \& J. Scott (eds), Law and New Governance in the EU and the US (Hart, 2006); C.F. Sabel \& J. Zeitlin, 'Learning from Difference: The New Architecture of Experimentalist Governance in the EU' (2008) 14(3) European Law Journal, pp. 271-327.

118 N. 85 above. 
'old governance' approach has since then often been replaced by new governance. The latter allows greater discretion to be left in the hands of Member States, affording them greater determination of their own path via a decentralized approach. The new EU approach to genetically modified organisms (GMOs) provides a good example, allowing for a degree of flexibility in Member State choices on the cultivation of GM crops on their territory. ${ }^{119}$ Renewables provide another example. The original EU Renewables Directive ${ }^{120}$ imposed binding (albeit differentiated) ${ }^{121}$ targets on Member States in order to reach the overall EU target. ${ }^{122}$ Even these binding targets allowed 'Member States a large discretion on the choice of national measures'. ${ }^{123}$ Nevertheless, the proposal for a revised Renewable Energy Directive goes one step further in abandoning binding national targets altogether. Instead, it maintains an overall target for the EU but, espousing a bottom-up perspective similar to that reflected in the nationally determined contributions of the Paris Agreement, the overall target is said to be best achieved through a partnership with Member States combining their national actions supported by a framework of measures as outlined in this Proposal'. ${ }^{124}$

However, it would be mistaken to see the old approach to EU environmental governance as wholly centralizing. After all, directives, which famously leave Member States a degree of implementing discretion, were a key source of law used at that time. ${ }^{125}$ Similarly, Article 193 of the Treaty on the Functioning of the European Union (TFEU) ${ }^{126}$ has long allowed Member States, in many circumstances, to adopt more stringent measures than those contained in EU legislation. ${ }^{127}$ EU environmental directives are seldom exhaustively harmonizing. Taking back control in this context therefore means taking back control to adopt weaker standards, because control to have stricter standards was already largely there under Article 193 TFEU.

It would be equally mistaken to claim that new governance is now wholly in the ascendant: in some areas, such as the EU ETS, initial decentralization (in setting national allocation plans (NAPs)) has since given rise to a more centralized system

119 M. Lee, 'The Ambiguity of Multi-Level Governance and (De)-harmonisation in EU Environmental Law' (2013) 15 Cambridge Yearbook of European Legal Studies, pp. 357-81; Dobbs, n. 72 above.

120 Directive 2009/28/EC on the Promotion of the Use of Energy from Renewable Sources and amending and subsequently repealing Directives 2001/77/EC and 2003/30/EC [2009] OJ L 140/16.

121 Ibid., Recital 15: 'The starting point, the renewable energy potential and the energy mix of each Member State vary. It is therefore necessary to translate the Community $20 \%$ target into individual targets for each Member State'.

122 Ibid., Recital 14: 'The main purpose of mandatory national targets is to provide certainty for investors'.

123 Proposal for a Directive on the Promotion of the Use of Energy from Renewable Sources, COM(2016) 767 final, p. 4.

124 Ibid. Member States will still have binding obligations to produce National Energy and Climate Plans and to report on these (under a separate proposal on the Energy Union Governance).

125 Although, as noted by Dobbs (n. 72 above, p. 248), there is an important difference between implementation power and the power to make policy decisions.

126 Lisbon (Portugal), 13 Dec. 2007, in force 1 Dec. 2009 [2010] OJ C 83/47, available at: http://eur-lex. europa.eu/LexUriServ/LexUriServ.do?uri=OJ:C:2012:326:FULL:EN:PDF.

127 D. Langlet \& S. Mahmoudi, EU Environmental Law and Policy (Oxford University Press, 2016), p. 102. 
(with the Commission setting an EU-wide cap on emissions). ${ }^{128}$ However, from a sovereignty and control perspective, the examples of new governance such as GMOs and renewables illustrate that EU environmental policy, especially in some of its more recent incarnations, does not always involve Member States losing all control to a highly centralized EU level. This phenomenon can also be explained through a multilevel governance (MLG) lens. ${ }^{129}$ MLG theory argues that not all power rests with states; rather, it is diffused across multiple levels, potentially from the local to the international. Therefore, to the extent that states retain a degree of sovereign policy decision-making power over particular EU policy areas like GMOs and renewables referred to above, then sovereignty and control exist at more than one level.

Nevertheless, while it is important to point to the overlapping issues of new governance and MLG in order to establish that Brexiteers would be mistaken in thinking of EU environmental policy as an area over which the UK had fully lost control (which needed to be regained), these considerations should not be read as wholesale normative support for such approaches. Where the EU acts in a way that is perceived by the environmental movement as anti-environmental - such as on the subject of GMOs - then, of course, there will be a temptation to support new governance flexibility for Member States, as this would allow them to make their own, more ambitious environmental choices. However, by and large, EU environmental policy is environmentally progressive. In most cases, new governance flexibility could result in Member States watering down standards, which can hardly be regarded as a good thing environmentally. It remains to be seen, for example, whether the bottom-up approach of the proposal for a revised Renewables Directive will be as effective environmentally as the existing Directive with its binding Member State targets. That Member States are capable of watering down can be seen in relation to the EU ETS, where a number of Member States had come up with very weak NAPs. This led to more recent EU centralization, away from the previous ineffective new governance-style NAPs. This more centralized approach is likely to be environmentally beneficial and to secure greater collective control over climate change than national control over NAPs provided. Hence, there is often much to be said for old governance and EU as opposed to national control may well produce better environmental outcomes.

In recent years, the MLG governance approach has also been particularly prevalent in the context of the perceived 'governance gap' in relation to climate change. ${ }^{130}$ The argument here is that lower governance levels (including cities ${ }^{131}$ and states within federal systems like that of the US) can to some extent make up for the

128 C. Hilson, 'It's All About Climate Change, Stupid! Exploring the Relationship between Environmental Law and Climate Law' (2013) 25(3) Journal of Environmental Law, pp. 359-70, 368. See also industrial emissions: Lee, n. 119 above.

129 On MLG see, e.g., Dobbs, n. 72 above.

130 L. Vanhala \& C. Hilson, 'Climate Change Litigation: Symposium Introduction' (2013) 35(3) Law \& Policy, pp. 141-9, at 143.

131 Via, e.g., the Covenant of Mayors, on which see further V. Heyvaert, 'What's in a Name? The Covenant of Mayors as Transnational Environmental Regulation' (2013) 22(1) Review of European, Comparative and International Environmental Law, pp. 78-90. 
lack of national and international progress on climate change. While this approach has a descriptive accuracy as well as a certain normative appeal, one should again be wary of attaching excessive importance to this perspective in relation to Brexit. While lower governance levels provide a much needed supplement to state and international action on climate change, they cannot provide a replacement for action at the latter levels. Thus, in the context of Brexit, the EU and climate change, and indeed environmental law more generally, one needs to beware of fallacious reasoning. The governance gap and the lessons from MLG that modern environmental law is not all about control at or by one single authority - the state - should not be misinterpreted as validating the proposition that any Brexit-resulting demise of forceful EU action on climate change or, indeed, any subsequent weakening of UK-level action in this area, is therefore unproblematic.

\section{CONCLUSION}

In assessing the environmental implications of Brexit, I have argued for a systematic and dynamic analysis of the effect on the environment of the UK's membership of the EU. However, this should not be taken as a claim that leaving may, somehow, not be so bad after all. A benefit of using a table like that presented in this article is that the balance of positives to negatives can easily be seen, and a glance at the table confirms that there are far more positives than negatives to the UK's existing relationship. The only way to preserve all of these would be by the UK remaining a full member. Given that this seems inconceivable, the second best solution would be an EEA-style soft Brexit or one where (unlike in the Swiss model) the EU insists on a considerable proportion of the environmental acquis being respected as a condition of single market membership. ${ }^{132}$ Although the EEA route also seems improbable, the election result of June 2017 makes some form of soft Brexit a more likely outcome. ${ }^{133}$ While these two particular soft Brexit options would not preserve the positive, top right box of Table 1, they would at least preserve much of the positive, bottom right qualities. However, even with a hard Brexit, given the single market influence, the bottom right and left boxes would not entirely disappear.

In considering issues of sovereignty and control in the specific context of environmental governance, I have stressed the importance of the principle of subsidiarity. Effective control over the environment often requires collaboration between states, particularly in the case of transboundary pollution or wildlife migration. While this might involve pooling sovereignty via multilateral or bilateral international agreements rather than via supranational EU-level action, the drafting and enforcement advantages of EU law mean that the latter will typically offer the most effective control. It also became clear that Brexit, depending on its eventual shape, is likely to give rise to contestation over environmental sovereignty and control

132 D. Boffey, 'MEPs in Bid to Force UK to Meet Environmental Regulations after Brexit', The Guardian, 31 Jan. 2017, available at: https://www.theguardian.com/politics/2017/jan/31/european-parliamentforce-uk-meet-environmental-regulations-after-brexit.

133 B. Maddox, 'What Does the Election Result Mean for Brexit?', Institute for Government, 9 June 2017, available at: https://www.instituteforgovernment.org.uk/blog/what-does-election-result-mean-brexit. 
within a devolved UK. In the absence of common EU federal action on the environment post-Brexit, subsidiarity suggests that there will be a need for the UK to create a similar centralized system internally in some areas of environmental policy. However, having fought hard for sovereignty over the environment as a devolved matter, the devolved administrations have already begun to express a degree of hostility towards the idea that Westminster might take back control at the centre when the EU environmental acquis is repatriated. In the end, then, the environment reveals sovereignty to be much more complicated than many Brexiteers may have imagined. The UK will still want many of the functions that the EU served in relation to the environment to be carried out. Taking the EU out of the equation simply means that these subsidiarity-justified functions have to be performed elsewhere: via international law cooperation and via central UK control. Pooling UK sovereignty with other states remains necessary for the former; and pooling at least some sovereignty that would otherwise be devolved seems inevitable for the latter. 